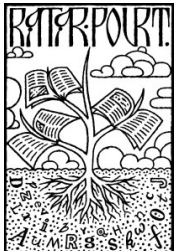

\title{
Seed nutrients and bioactive compounds of underutilised oil crop Carthamus tinctorius L.
}

\author{
Biljana Kiprovski · Simona Jaćimović · Nada Grahovac · \\ Tijana Zeremski · Ana Marjanović Jeromela
}

Institute of Field and Vegetable Crops, Novi Sad, Serbia

\begin{abstract}
Summary: Seeds of seven different genotypes of underutilised oil crop Carthamus tinctorius L. (Asteraceae) from alternative oil species collection of the Institute of Field and Vegetable Crops (Novi Sad, Serbia), were analysed for their protein, oil, fatty acids, tocopherols and total phenolics contents, with a view to test their diversity and potential as an alternative source of these valuable compounds. Seeds of the tested safflower genotypes had total protein (determined by Kjeldahl method) content from 11.5 to $16.0 \%$, while total oil content (determined by Soxhlet method) ranged from 16.8 to $24.5 \%$ of dry matter, on average. Two main unsaturated fatty acids in safflower seeds, oleic and linoleic acids, represent approximately $90 \%$ of the total fatty acid content (determined by gas chromatography). Linoleic acid was the dominant fatty acid in all genotypes (61.2-80.2\% of oil), while oleic acid was in a negative correlation with linolenic acid content and ranged from 9.6 to $29.5 \%$ of oil. The amount of saturated fatty acids ranged from 5.5 to $6.05 \%$ for palmitic, and 2.1 to $3.5 \%$ for stearic acid. Safflower seed is a source of $\alpha$-tocopherol (determined by high performance liquid chromatography method with fluorescence detection) and its amount ranged from 358.8 to $461.8 \mathrm{mg} / \mathrm{L}$ of oil. The content of total phenolics (determined spectrophotometrically) ranged from 4.0 to $6.0 \mathrm{mg}$ of gallic acid equivalents/g of dry weight. This comprehensive screening of valuable chemical compounds of safflower seeds shows the importance of this alternative oil seed crop as a good source of important nutrients and bioactive constituents.

Key words: alternative oil crops, Carthamus tinctorius L., fatty acids, nutritional quality, oils, proteins, safflower,
\end{abstract} tocopherols, total phenolics, $\alpha$-tocopherol

\section{Introduction}

Safflower (Carthamus tinctorius L.) is an annual crop which belongs to Asteraceae (Compositae) family. It is a highly branched, herbaceous, thistle-like annual, usually with many long sharp spines on the leaves and bracts or without them (Figure $1 \mathrm{~A}$ and B). Plants are 30-150

\section{Corresponding author:}

biliana.kiprovski@ifvens.ns.ac.rs

Acknowledgements:

This research was supported by the Ministry of Education, Science and Technological Development of the Republic of Serbia, grant number: 451-039/2021-14/200032.

Cite this article:

Kiprovski B., Jaćimović S., Grahovac N., Zeremski T., Marjanović Jeromela A. (2021). Seed nutrients and bioactive compounds of underutilised oil crop Carthamus tinctorius L. Ratar. Povrt., 58 (2), 46-52
(210) cm tall, with globular flower heads (capitula), which comprise of brilliant yellow, orange or red flowers (Dajue \& Mündel, 1996). Each flower head contains 15 to 20 seeds per head (Figure 1C). Achenes are smooth, four-sided and generally lack of pappus. It develops a deep taproot (up to $1 \mathrm{~m}$ depth) which enables it to thrive in arid environments with seasonal rain. It has an ability to withstand drought, strong winds, hail storms and flooding. Safflower flowers have been used like colorant of food and fabrics, especially before less expensive aniline dyes became available. Today, safflower is used as an oilseed crop, mostly used for edible oil (salad oil, oil for cooking and margarine) and as birdseed, livestock forage, tea, biodiesel production, etc. Its maximum production cycle is equal to $130-140$ days, so it can be intercropped in temperate climates or have two crops in semi-arid climate (Herdrich, 2001)

It is grown mostly in Asia and Americas, with over half of its production in India (mainly for the domestic vegetable oil market) (FAOSTAT, 1994-2019). An average global yield of safflower seeds reaches up to 900 


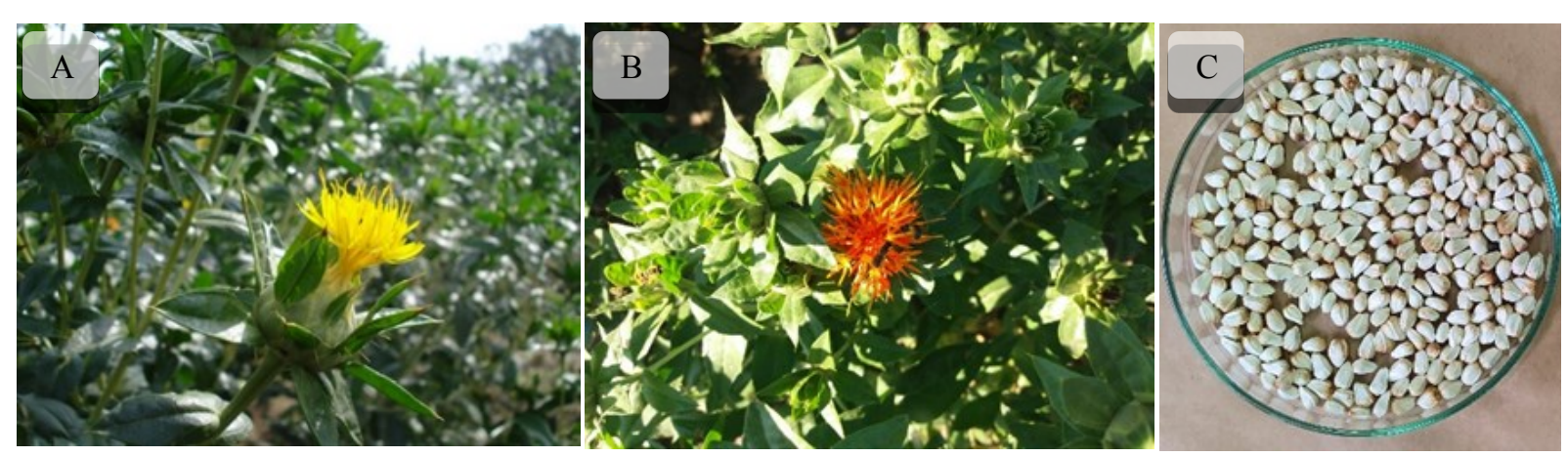

Figure 1. Safflower plants (A, B) and seeds (C)

$\mathrm{kg} / \mathrm{ha}$, however, in the recent years, harvest area and production is lower than in the past (FAOSTAT, 19942019).

The hull fraction of safflower seeds is $35-45 \%$. Depending on the hull size, the oil content of the seed ranges between 20 and 47\% (Cosge et al., 2007; Yeloojeh et al., 2020; Kutsenkova et al., 2020). The whole seeds in normal hull types contain $27-32 \%$ of oil, $5-8 \%$ of moisture, $14-17 \%$ of protein, $2-7 \%$ of ash, and $32-40 \%$ of crude fiber (Gecgel et al., 2007, Kutsenkova et al., 2020).

Safflower has multiple usage possibilities, but its potential depends of growing region, the reason of which it is important to test their growing capacity in agroecological conditions of interest.

The aim of this paper was to analyse seeds of seven different genotypes of underutilised oil crop Carthamus tinctorius L., grown under agroecological conditions of Serbia, on their protein, oil, fatty acids, tocopherols and total phenolics contents, with a view to test their biochemical diversity and potential as an alternative source of these valuable compounds.

\section{Material and methods}

Safflower genotypes (Table 1) used in this research are a part of the collection of alternative oil species of the Institute of Field and Vegetable Crops (Novi Sad, Serbia).

Seed samples analysed in this paper were harvested in 2017. Each plot in the experiment consisted of 4 rows, which were $3.6 \mathrm{~m}$ long, with $0.25 \mathrm{~m}$ between rows. The harvest area of individual plot was $3.6 \mathrm{~m}^{2}$. Plants were grown under isolation. Sowing and harvest were performed manually.

All seeds were pre-dried at $50{ }^{\circ} \mathrm{C}$ for $24 \mathrm{~h}$ to obtain moisture content below $8 \%$ (moisture content determined gravimetrically, by drying at $103{ }^{\circ} \mathrm{C}$, for $3 \mathrm{~h}$ ).

Seeds were ground in a laboratory mill (IKA $\AA$, A11 basic, Germany) and sieved into $1 \mathrm{~mm}$ fractions. Total oil content in seeds was determined by Soxhlet extraction procedure. Protein content was determined by Kjeldahl method, according to the manufacturer's instructions (Gerhardt, 2003). The fatty acid profiles of safflower seed oil were measured by gas chromatography method described by Dimitrijević et al. (2017). Components of safflower seed oil saponifiable fractions was esterified using trimethylsulfonium hydroxide solution to their volatile fatty acid methyl esters (FAMEs). The results were expressed as the percentage of individual fatty acids of the content of the oil. Tocopherol content was performed by high performance liquid chromatography (HPLC) with fluorescence detection, according to an AOCS standard method (Ce 8-89). The results were expressed as milligram of individual tocopherol per litre of the oil $(\mathrm{mg} / \mathrm{L})$. Total phenolics contents was determined by The Folin-Ciocâlteu reagent, spectrophotometrically (Makkar, 2003) and expressed as $\mathrm{mg}$ of gallic acid equivalents per $\mathrm{g}$ of dry seed.

Values of the biochemical parameters were expressed as means \pm standard error of determinations

Table 1. Name and source of the genotype, year of introduction into collection, flower colour and presence of spines (+ present, - absent)

\begin{tabular}{llcccc}
\hline & Genotype & Source & In collection since & Flower colour & Spines \\
\hline 1 & Sunčana - СОНЯЧНИЙ & Ukraine & 2004 & red & + \\
2 & Bird 1 & bird food 1 & 2009 & orange & + \\
3 & Liman & Liman local market & 2009 & orange & - \\
4 & Bird 2 & bird food 2 & 2011 & orange & + \\
5 & 'Remzibey' & Turkey & 2014 & yellow & + \\
6 & 'Dinçer' & Turkey & 2014 & orange & + \\
7 & 'Yenice' & Turkey & 2014 & red & + \\
\hline
\end{tabular}


made in triplicates and tested by ANOVA followed by comparisons of means by the Duncan's test $(p<0.05)$. All statistical analyses were performed using STATISTICA for Windows version 13 (Dell Software, Dell Inc., Aliso Viejo, CA, USA).

\section{Results and discussion}

Recently there has been alternation between drought and flood seasons in Serbia and other regions, which is why the importance of plant adaptation and agrobiodiversity has become one of the primary focuses. Being adaptable to arid conditions, with seasons of heavy rain, safflower has a potential in sustainable plant production.

Depending on the genetics of the safflower line, three types of oil can be produced: high in linoleic acid $(>70 \%)$, high in oleic acid $(>70 \%)$, and almost equal amounts of oleic and linoleic acids in oil (Ahmadzadeh et al., 2014).

The oil content in the tested seeds was $16.8-24.5 \%$ (Figure 2), but published data show values up to $38 \%$, mostly for cultivars from Turkey that are grown in the Mediterranean regions of the country during winter (Samancı \& Özkaynak 2003; Coşge et al., 2007; Esendal et al., 2008; Coşge et al., 2008). The same data showed $5 \%$ higher values of oil content in seeds sown in winter, compared to these sown in spring, however spring sowing results are similar to findings reported in this paper.

Frost during kernel filling can radically lower yields and oil content, or destroy the seed completely, due to sensitivity of genes for fatty acid synthesis to low temperatures (Dajue \& Mündel, 1996), which could result in reduction of stearic and oleic acids and increase in linoleic acid (Ladd \& Knowles, 1971). The three genes that control production of oleic, linoleic and stearic acids (ol ol, li li and st st, respectively), appear to be the major recessive genes at different loci. In certain genotypes, synthesis and accumulation of stearic acid is negatively correlated to accumulation of oleic or linoleic acid or both (Ladd \& Knowles, 1971).

Dajue \& Mündel (1996) proposed five groups of safflower lines and possible genotypes according to fatty acid composition and content, which positions genotypes tested in this research into three groups: very high linoleic ('Remzibey'), high linoleic ('Yenice') and high stearic (the rest of the tested genotypes).

High oleic acid content in safflower is inherited and controlled by a partially recessive allele, 'ol' at a single locus 'OL' (Hamdan et al., 2009). According to Hamdan et al. (2012), microsomal oleoylphosphatidylcholine desaturase FAD2-1 gene underlies the 'OL' locus. FAD2 enzyme catalyses conversion of oleic acid into linoleic acid during lipid biosynthesis (Okuley et al., 1994). There are data on the development of molecular marker assay applied to predict high oleic acid content in safflower. It is based on the fact that the DNA sequence variates between large introns situated in the 5' UTR of CtFAD2-1 and CtFAD2-1', fatty acid desaturase gene and its affected variant, respectively (CtFAD2-1' conventionally designated as 'ol' allele) (Liu et al., 2013).

Variation of safflower oil content depends on the process and technique of oil extraction (Han et al., 2009). In general, all safflower genotypes in our collection have high amount of linoleic acid (polyunsaturated fatty acid, PUFA) content (Table 2). Oleic and linoleic acids were the two major unsaturated fatty acids in these safflower seeds. According to the

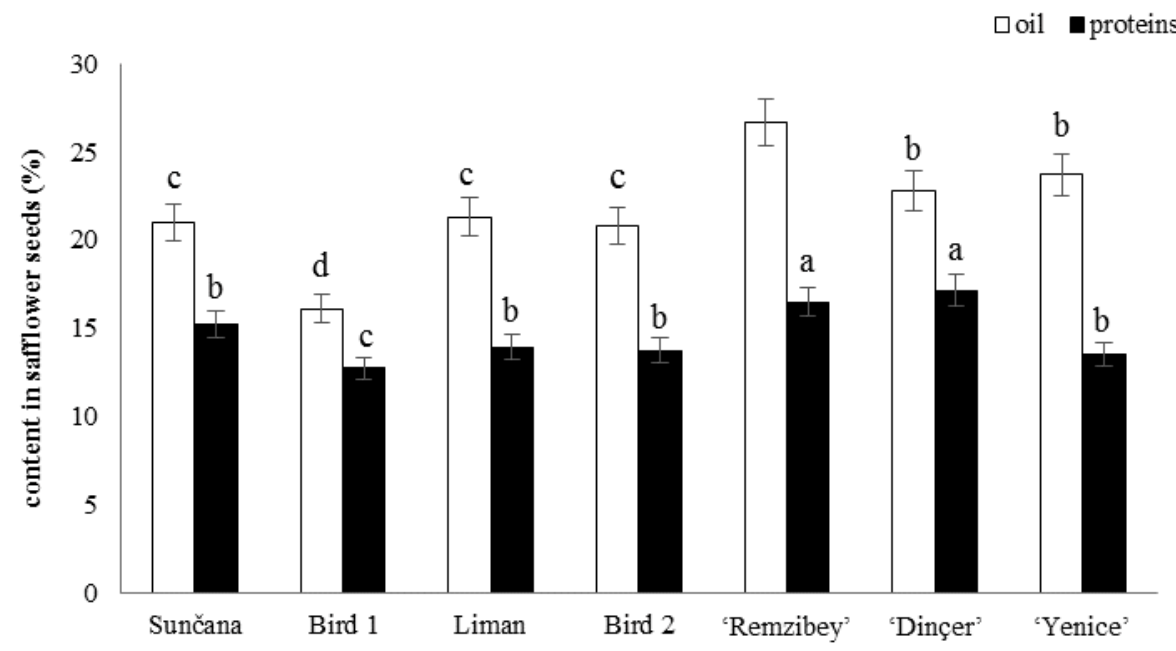

Figure 2. Oil and protein content in safflower seeds. Values marked with the different letter differ significantly among genotypes at $\mathrm{p}<0.05$ (Duncan's test). 
Table 2. Average fatty acid content (\% of oil) in safflower seeds (mean \pm standard error of mean). Values marked with the different letter differ significantly among genotypes at p<0.05 (Duncan's test). *Coşge et al., 2007; Mailer et al., 2008; Sabzalian et al., 2008; Ben Moumen et al., 2013; Kostik et al., 2013; Al Surmi et al., 2015; Kutsenkova et al., 2020; Yeloojeh et al., 2020)

\begin{tabular}{|c|c|c|c|c|c|c|c|c|c|c|}
\hline & Myristic & Palmitic & Stearic & Oleic & Linoleic & Linolenic & Arachidic & $\begin{array}{c}\text { Eicosapen- } \\
\text { taenoic }\end{array}$ & Behenic & Lignoceric \\
\hline Sunčana & $0.13 \pm 0.00 \mathrm{a}$ & $5.54 \pm 0.02 \mathrm{~b}$ & $2.43 \pm 0.10 \mathrm{c}$ & $11.46 \pm 0.03 \mathrm{e}$ & $79.62 \pm 0.11 \mathrm{a}$ & $0.19 \pm 0.01 \mathrm{c}$ & $0.24 \pm 0.01 \mathrm{c}$ & $0.15 \pm 0.01 \mathrm{c}$ & $0.13 \pm 0.03 \mathrm{~d}$ & $0.07 \pm 0.01 \mathrm{ab}$ \\
\hline Bird 1 & $0.12 \pm 0.01 \mathrm{a}$ & $6.27 \pm 0.02 \mathrm{a}$ & $3.53 \pm 0.02 \mathrm{a}$ & $15.98 \pm 0.24 b$ & $72.48 \pm 0.51 \mathrm{~d}$ & $0.62 \pm 0.27 \mathrm{a}$ & $0.40 \pm 0.00 \mathrm{a}$ & $0.20 \pm 0.01 \mathrm{a}$ & $0.24 \pm 0.00 \mathrm{a}$ & $0.09 \pm 0.00 \mathrm{a}$ \\
\hline Liman & $0.12 \pm 0.00 \mathrm{a}$ & $5.28 \pm 0.04 \mathrm{c}$ & $2.38 \pm 0.07 \mathrm{c}$ & $13.90 \pm 0.39 \mathrm{c}$ & $77.16 \pm 0.62 \mathrm{~b}$ & $0.43 \pm 0.17 \mathrm{ab}$ & $0.26 \pm 0.01 \mathrm{c}$ & $0.18 \pm 0.01 \mathrm{~b}$ & $0.18 \pm 0.01 \mathrm{c}$ & $0.06 \pm 0.01 \mathrm{~b}$ \\
\hline Bird 2 & $0.12 \pm 0.00 \mathrm{a}$ & $5.91 \pm 0.15 \mathrm{a}$ & $3.36 \pm 0.03 \mathrm{~b}$ & $14.34 \pm 0.06 \mathrm{c}$ & $75.24 \pm 0.16 \mathrm{c}$ & $0.19 \pm 0.00 \mathrm{c}$ & $0.35 \pm 0.01 \mathrm{~b}$ & $0.19 \pm 0.00 \mathrm{~b}$ & $0.20 \pm 0.01 \mathrm{~b}$ & $0.09 \pm 0.01 \mathrm{a}$ \\
\hline 'Remzibey' & $0.11 \pm 0.00 \mathrm{a}$ & $5.62 \pm 0.05 b$ & $2.52 \pm 0.03 \mathrm{c}$ & $29.53 \pm 0.25 \mathrm{a}$ & $61.18 \pm 0.26 \mathrm{e}$ & $0.22 \pm 0.03 \mathrm{~b}$ & $0.31 \pm 0.01 \mathrm{~b}$ & $0.20 \pm 0.01 \mathrm{a}$ & $0.21 \pm 0.00 \mathrm{~b}$ & $0.08 \pm 0.00 \mathrm{ab}$ \\
\hline 'Dinçer' & $0.12 \pm 0.01 \mathrm{a}$ & $6.03 \pm 0.07 \mathrm{a}$ & $2.14 \pm 0.03 \mathrm{~d}$ & $13.19 \pm 0.22 \mathrm{~d}$ & $77.66 \pm 0.19 \mathrm{~b}$ & $0.23 \pm 0.03 \mathrm{~b}$ & $0.25 \pm 0.00 \mathrm{c}$ & $0.12 \pm 0.01 \mathrm{~d}$ & $0.17 \pm 0.01 \mathrm{c}$ & $0.07 \pm 0.01 \mathrm{ab}$ \\
\hline 'Yenice' & $0.12 \pm 0.01 \mathrm{a}$ & $5.92 \pm 0.07 \mathrm{a}$ & $3.18 \pm 0.08 \mathrm{~b}$ & $9.60 \pm 0.11 \mathrm{f}$ & $80.24 \pm 0.15 \mathrm{a}$ & $0.22 \pm 0.03 \mathrm{~b}$ & $0.31 \pm 0.01 \mathrm{~b}$ & $0.15 \pm 0.01 \mathrm{c}$ & $0.18 \pm 0.01 \mathrm{c}$ & $0.08 \pm 0.01 \mathrm{ab}$ \\
\hline $\begin{array}{c}\text { Literature } \\
\text { data* }\end{array}$ & $01-0.5$ & $4-8.6$ & $1.7-2.80$ & 8.1-18.4 & $71.5-83.7$ & $0.07-0.1$ & $0-0.4$ & $0-0.2$ & & \\
\hline
\end{tabular}

literature, similar findings and values were reported by various authors (Coşge et al., 2007; Mailer et al., 2008; Sabzalian et al., 2008; Ben Moumen et al., 2013; Kostik et al., 2013; Al Surmi et al., 2015; Khalid et al., 2017; Kutsenkova et al., 2020; Yeloojeh et al., 2020).

Although beneficial for human consumption, edible oil that is rich in PUFA is prone to oxidation, which leads to instability and short shelf life. To prevent deterioration of oil, process of oil hydrogenisation is mostly applied, however it results in the formation of trans fats. Contrary to this, high oleic acid (monounsaturated fatty acid, MUFA) is more stable (a heat-tolerant cooking oil), has extended shelf life and is preferable to the food industry for production of margarines, salad dressings, infant formulas and food coatings. All these facts make oleic acid-rich oil crop varieties more interesting, which stands for safflower genotypes, as well.
Tocopherols found in tested samples belong to $\alpha$ tocopherol group (358.8-461.8 mg/L of oil). Compared to the literature data (Mailer et al., 2008; Aydeniz et al., 2014; Matthaus et al., 2015; Topkafa, 2016; Celenk et al., 2018; Ergönül \& Özbek, 2018), it can be concluded that tocopherols values of tested genotypes are within the range of published data ( $\alpha$-tocopherol $46-1310 \mathrm{mg} /$ $\mathrm{kg}$ ). However, some of the cited literature data point to presence of $\beta$-tocopherols (4-21.6 mg/kg), $\gamma$-tocopherols (4.5-25 mg/kg), $\gamma$-tocotrienols $(9.7 \mathrm{mg} / \mathrm{kg})$ and $\mathrm{d}-$ tocopherol $(1.0 \mathrm{mg} / \mathrm{kg})$ that were absent in our samples.

Protein content was up to $16 \%$ (Figure 2), which was similar to the available literature (Khalid et al., 2017; Kutsenkova et al., 2020). Cold pressed cakes from safflower seeds are mostly used as feed and production of biochar fertilizer (Angin, 2013).

Total phenolics content in tested safflower seed samples ranges from 4-6 mg GAE/g while literature

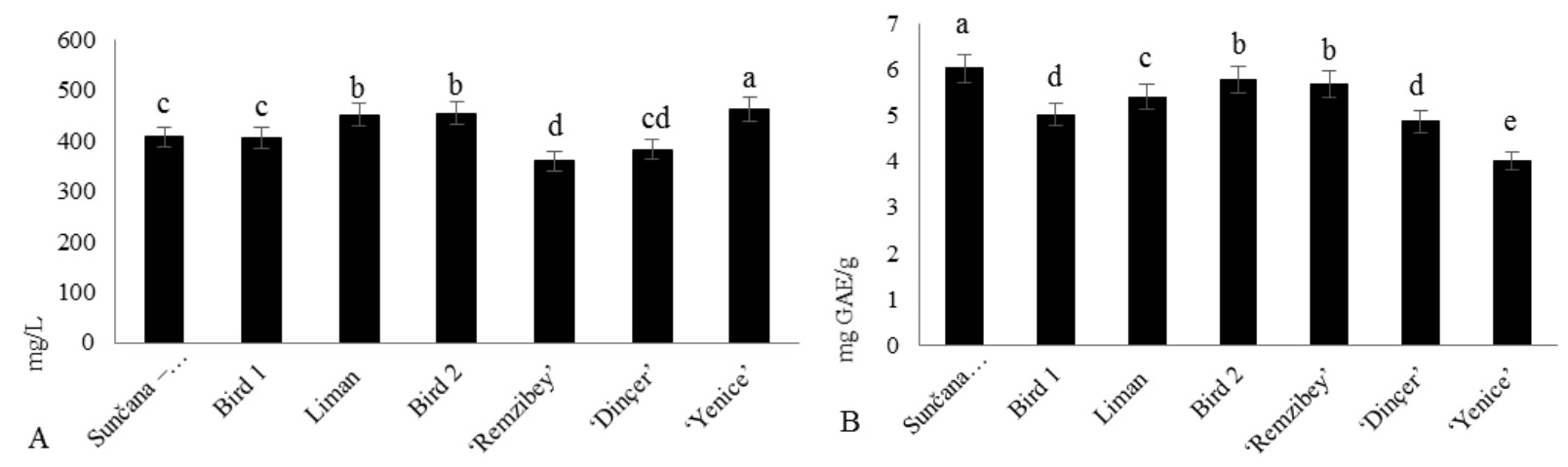

Figure 3. Tocopherol ( $\alpha$-tocopherol) (A) and total phenolics (B) contents in seeds of safflower seeds. Values marked with the different letter differ significantly among genotypes at $\mathrm{p}<0.05$ (Duncan's test). 
data point to much higher values, which depends on extraction procedures, experiment and genotype, as well. Ergönül \& Özbek (2018) revealed the effect of variety on bioactive compounds of cold pressed safflower seeds and reported values for total phenolic content were up to $53.9 \mathrm{mg} / \mathrm{g}$. The major phenolic compounds detected in safflower seeds were: flavones apigenin (as the main phenolic compound) and luteolin, hydroxybenzoic acids (vanillic acid and syringic acid), hydroxycinnamic acids (p-coumaric acid, cinnamic acid, sinapic acid, and ferulic acid), as well as flavanols (epigallocatechin and gallocatechin) (Mailer et al., 2008; Yu, et al., 2013; Moumen et al., 2015; Ergönül \& Özbek, 2018).

Due to its bioactive compounds, safflower has antioxidant, antitumor, cardio-protective, hepatoprotective, phytoestrogens related, anti-diabetic and anti-obesity, and skin health properties (reviewed in Khalid et al., 2017).

The analysed data show that safflower cultivars have higher amounts of oil, oleic and linoleic acids contents, as well as $\alpha$-tocopherols content. Further breeding objectives would include higher seed oil contents without affecting oil and protein content in seed, as well as disease resistance/tolerance and tolerance to abiotic factors. In recent years, the only infectious disease that was detected in the tested safflower collection was viral infection (alfalfa and cucumber mosaic viruses), both reported by Milosević et al. (2015 and 2020).

From the aspect of sustainable agricultural production, minor or underutilized oil crops could have an added value and could contribute to a better crop rotation (short cycle oil crop), growing at small areas/ households, additional income to small producers, agrobiodiversity, food diversity, etc.

\section{References}

Ahmadzadeh, S., Kadivar, M., Saeidi, G. (2014). Investigation of oil properties and seed composition in some safflower lines and cultivars. Journal of Food Biochemistry, 38(5), 527-532. https:// doi.org/10.1111/jfbc.12091

Al Surmi, N. Y., El Dengawi, R. A. H., Khalefa, A. H., Yahia, N. (2015) Characteristics and oxidative stability of some safflower (Carthamus tinctorius L.). Journal of Nutrition \& Food Sciences, 14, 2. https:// doi.org/10.4172/2155-9600.S14-001

Alihosseini, F. and Sun, G. (2011). 17-Antibacterial colorants for textiles. In N. Pan, G. Sun (Eds.) Functional textiles for improved performance, protection and health (pp. 376-403). Woodhead Publishing. https:// doi.org/10.1533/9780857092878.376

Angin, D. (2013). Effect of pyrolysis temperature and heating rate on biochar obtained from pyrolysis of safflower seed press cake. Bioresource Technology, 128, 593-597. https://doi.org/10.1016/ j.biortech.2012.10.150

AOCS 1994. American Oil Chemists' Society standard method (Ce 8-89), 4th (ed.; Firestone, D.). Champaign, IL: AOCS Press.

Aydeniz, B., Güneşer, O., Yılmaz, E. (2014). Physico-chemical, sensory and aromatic properties of cold press produced safflower oil. Journal of the American Oil Chemists' Society, 91(1), 99-110. https:// doi.org/10.1007/s11746-013-2355-4

Ben Moumen, A., Mansouri, F., Richard, G., Abid, M., Fauconnier, M.L., Sindic, M., El Amrani, A., Serghini Caid, H. (2015). Biochemical characterisation of the seed oils of four safflower (Carthamus tinctorius) varieties grown in north $\square$ eastern of Morocco. International Journal of Food Science \& Technology, 50(3), 804-810.

Ben Moumen, A., Mansouri, F., Zraibi, L., Abid, M., Nabloussi, A., Fauconnier, M.L., Sindic, M., Serghini-Caid, H. (2013). Comparative study of four safflower oils (Carthamus tinctorius) varieties grown in eastern of Morocco. In Book of Proceedings InsideFood Symposium (p. 6).

Celenk, V. U., Gumus, Z. P., Argon, Z. U., Buyukhelvacigil, M., Karasulu, E. (2018). Analysis of chemical compositions of 15 different cold-pressed oils produced in Turkey: a case study of tocopherol and fatty acid analysis. Journal of the Turkish Chemical Society Section A: Chemistry, 5(1), 1-18. http://doi.org/10.18596/ jotcsa.335012

Coşge, B. \& Demir, K.A.Y.A. (2008). Performance of some safflower (Carthamus tinctorius L.) varieties sown in late-autumn and late-spring. Süleyman Demirel Üniversitesi Fen Bilimleri Enstitüsü Dergisi, 12(1), 13-18.

Coşge, B., Gürbüz, B., Kiralan, M. (2007). Oil content and fatty acid composition of some safflower (Carthamus tinctorius L.) varieties sown in spring and winter. International Journal of Natural \& Engineering Sciences, 1(3).

Dajue Li \& Hans-Henning Mündel. (1996). Safflower. Carthamus tinctorius L. Promoting the conservation and use of underutilized and neglected crops. 7. Rome, Italy: Institute of Plant Genetics and Crop Plant Research, Gatersleben/International Plant Genetic Resources Institute.

de Oliveira, C.V.K., Santos, R.F., Siqueira, J.A.C., Bariccatti, R.A., Lenz, N.B.G., Cruz, G.S., Tokura, L.K., Klajn, F.F. (2018). Chemical characterization of oil and biodiesel from four safflower genotypes. Industrial Crops and Products, 123, 192-196. https://doi.org/10.1016/ j.indcrop.2018.06.035

Dimitrijević, A., Imerovski, I., Miladinović, D., Cvejić, S., Jocić, S., Zeremski, T., Sakač, Z. (2017). Oleic acid variation and markerassisted detection of Pervenets mutation in high-and low-oleic sunflower cross. Crop Breeding and Applied Biotechnology, 17(3), 235241. http://dx.doi.org/10.1590/1984-70332017v17n3a36

Ergönül, P.G. \& Özbek, Z.A. (2020). Cold pressed safflower (Carthamus tinctorius L.) seed oil. In M.F. Ramadan (Ed.), Cold Pressed Oils. Green Technology, Bioactive Compounds, Functionality, and Applications, (pp. 323333). Academic Press. https://doi.org/10.1016/C2018-0-03151-5

Esendal, E., Arslan, B., Paşa, C. (2008). Effect of winter and spring sowing on yield and plant traits of safflower (Carthamus tinctorius L.). In Proceedings of 7th International Safflower Conference (pp. 3-7).

FAOSTAT (FAOSTAT, 19942019). http://www.fao.org/faostat/en/ \#data (accessed on 22 Feb 2021).

Gecgel, U., Demirci, M., Esendal, E., Tasan, M. (2007). Fatty acid composition of the oil from developing seeds of different varieties of safflower (Carthamus tinctorius L.). Journal of the American Oil Chemists' Society, 84(1), 47-54. https://doi.org/10.1007/s11746-0061007-3

Gerhardt. (2003). Manufacturer's specifications Crude proteins in seed and products (ICC-Standard No. 105 i AOAC Official Method 979,09, Protein in Grain)

Golkar, P. (2018). Inheritance of carthamin and carthamidin in safflower (Carthamus tinctorius L.). Journal of Genetics, 97(1), 331-336. https:// doi.org/10.1007/s12041-018-0909-9

Hamdan, Y. A., García-Moreno, M. J., Fernández-Martínez, J. M., Velasco, L., Pérez-Vich, B. (2012). Mapping of major and modifying genes for high oleic acid content in safflower. Molecular Breeding, 30 (3), 1279-1293. https://doi.org/10.1007/s11032-012-9714-y

Hamdan, Y. A., Pérez-Vich, B., Velasco, L., Fernández-Martínez, J. M. (2009). Inheritance of high oleic acid content in safflower. Euphytica, 168(1), 61-69. https://doi.org/10.1007/s10681-008-9879-y

Han, X., Cheng, L., Zhang, R., Bi, J. (2009). Extraction of safflower seed oil by supercritical CO2. Journal of Food Engineering, 92(4), 370-376. https://doi.org/10.1016/j.jfoodeng.2008.12.002

Herdrich, N. (2001). Safflower Production Tips/Alternative Crops for Dryland Agriculture in the Intermountain Pacific Northwest. Cooperative extension Washington State University. EB1890. https:// research.wsulibs.wsu.edu:8443/xmlui/bitstream/ handle/2376/6906/eb1890.pdf?sequence $=1$ \&isAllowed $=\mathrm{y}$

Kadirvel, P., Veerraju, C., Senthilvel, S., Yadav, P., Kiran, B.U., Shaik, M., Shaw, R., Selvaraj, V.M., Reddy, Y.R., Mohanrao, M.D., Mukta, N. 
(2020). Marker-assisted selection for fast-track breeding of high oleic lines in safflower (Carthamus tinctorious L.). Industrial Crops and Products, 158, 112983. https://doi.org/10.1016/j.indcrop.2020.112983

Khalid, N., Khan, R.S., Hussain, M.I., Farooq, M., Ahmad, A., Ahmed, I. (2017). A comprehensive characterisation of safflower oil for its potential applications as a bioactive food ingredient-A review. Trends in Food Science \& Technology, 66, 176-186. https://doi.org/10.1016/ j.tifs.2017.06.009

Kostik, V., Memeti, S., Bauer, B. (2013). Fatty acid composition of edible oils and fats. Journal of Hygienic Engineering and Design, 4, 112-116. https://eprints.ugd.edu.mk/id/eprint/11460

Kutsenkova, V.S., Nepovinnykh, N.V., Guo, Q., 2020. Using of safflower seeds as a protein fortifier for shortbread. Food Hydrocolloids, 105, 105808. https://doi.org/10.1016/j.foodhyd.2020.105808

Ladd, S. L., \& Knowles, P. F. (1971). Interactions of alleles at two loci regulating fatty acid composition of the seed oil of safflower (Carthamus tinctorius L.). Crop Science, 11(5), 681-684. https:// doi.org/10.2135/cropsci1971.0011183X001100050024x

Liu, Q., Cao, S., Zhou, X. R., Wood, C., Green, A., Singh, S. (2013). Nonsense-mediated mRNA degradation of CtFAD2-1 and development of a perfect molecular marker for olol mutation in high oleic safflower (Carthamus tinctorius L.). Theoretical and Applied Genetics, 126(9), 2219-2231. https://doi.org/10.1007/s00122-013-2129-2

Machewad, G. M., Ghatge, P., Chappalwar, V., Jadhav, B., Chappalwar, A. (2012). Studies on extraction of safflower pigments and its utilization in ice cream. Journal of Food Processing and Technology, 3(8). https://doi.org/10.4172/2157-7110.1000172

Mailer, R., Potter, T., Redden, R., Ayton, J. (2008). Quality evaluation of safflower (Carthamus tinctorius L.) cultivars. In 7 th International Safflower Conference, Wagga Wagga, NSW (pp. 3-6).

Makkar, H.P.S. (2003). Quantification of tannins in tree and shrub foliage: a laboratory manual. The Netherlands: Springer Kluwer Academic Publishers. https://doi.org/10.1007/978-94-017-0273-7

Manufacturer's specifications Gerhardt. (2003). Crude proteins in seed and products (ICC-Standard No. 105 and AOAC Official Method 979,09, Protein in Grain).

Marjanović Jeromela A, Kondić-Špika A, Miladinović D, Dimitrijević A, Imerovski I, Jocković M, Simić A, Terzić S. (2016). Phenotypic and molecular evaluation of genetic diversity in NS safflower (Carthamus tinctorius L.) collection. Matica Srpska Journal of Natural Sciences, 131, 91 -98. https://doi.org/10.2298/ZMSPN1631091M

Matthaus, B., Özcan, M. M., Al Juhaimi, F.Y. (2015). Fatty acid composition and tocopherol profiles of safflower (Carthamus tinctorius L.) seed oils. Natural Product Research, 29(2), 193-196. https:// doi.org/10.1080/14786419.2014.971316

Milošević, D., Ignjatov, M., Marjanović-Jeromela, A., Nikolić, Z., Tamindžić, G., Miljaković, D., Stanković, I. (2020). Presence and molecular characterization of cucumber mosaic virus on safflower in Serbia. Ratarstvo i povrtarstvo, 57(2), 49-54. https://doi.org/10.5937/ ratpov57-25745

Milošević, D., Marjanović Jeromela, A., Jovičić, D., Ignjatov, M., Nikolić, Z., Terzić, S., Stanković, I. (2015). First report of Alfalfa mosaic virus on safflower in Serbia. Plant Disease, 99(6), 896-896. https:// doi.org/10.1094/PDIS-12-14-1267-PDN

Oelke, E.A., Oplinger, E.S., Teynor, T.M., Putnam, D.H., Doll, J.D., Kelling, K.A., Durgan, B.R., Noetzel, D.M. (1992). Safflower. Alternative Field Crops Manual. University of Wisconsin-Exension, Cooperative Extension. http://www.hort.purdue.edu/newcrop/ afcm/safflower.html

Okuley, J., Lightner, J., Feldmann, K., Yadav, N., Lark, E. (1994). Arabidopsis FAD2 gene encodes the enzyme that is essential for polyunsaturated lipid synthesis. The Plant Cell, 6(1), 147-158. https:// doi.org/10.1105/tpc.6.1.147

Sabzalian, M. R., Saeidi, G., Mirlohi, A. (2008). Oil content and fatty acid composition in seeds of three safflower species. Journal of the American Oil Chemists' Society, 85(8), 717-721. https://doi.org/10.1007/s11746008-1254-6

Samanc1, B. \& Özkaynak, E. (2003). Effect of planting date on seed yield, oil content and fatty acid composition of safflower (Carthamus tinctorius) cultivars grown in the Mediterranean region of Turkey.
Journal of Agronomy and Crop Science, 189(5), 359-360. https:// doi.org/10.1046/j.1439-037X.2003.00053.x

Sehgal, D. \& Raina, S.N. (2011). Carthamus. In: Kole C. (Ed.) Wild Crop Relatives: Genomic and Breeding Resources. Springer, Berlin, Heidelberg. https://doi.org/10.1007/978-3-642-14871-2_4

SRPS EN ISO 665 (2008). Oilseeds — Determination of moisture and volatile matter content.

Topkafa, M. (2016). Evaluation of chemical properties of cold pressed onion, okra, rosehip, safflower and carrot seed oils: triglyceride, fatty acid and tocol compositions. Analytical methods, 8(21), 4220-4225. https://doi.org/10.1039/C6AY00709K

Yeloojeh, K.A., Saeidi, G., Sabzalian, M.R. (2020). Drought stress improves the composition of secondary metabolites in safflower flower at the expense of reduction in seed yield and oil content. Industrial Crops and Products, 154, 112496. https://doi.org/10.1016/ j.indcrop.2020.112496

Yu, S.Y., Lee, Y.J., Kim, J.D., Kang, S.N., Lee, S.K., Jang, J.Y., Lee, H.K., Lim, J.H., Lee, O.H., (2013). Phenolic composition, antioxidant activity and anti-adipogenic effect of hot water extract from safflower (Carthamus tinctorius L.) seed. Nutrients, 5(12), 4894-4907. https://dx.doi.org/10.3390\%2Fnu5124894

Yusuf, M., Shabbir, M., Mohammad, F. (2017). Natural colorants: Historical, processing and sustainable prospects. Natural Products and Bioprospecting 7, 123-145. https://doi.org/10.1007/s13659-017-0119 $-9$ 


\section{Hranljive materije i bioaktivna jedinjenja semena manje gajene uljane vrste Carthamus tinctorius $\mathrm{L}$.}

\section{Biljana Kiprovski · Simona Jaćimović · Nada Grahovac · Tijana Zeremski · Ana Marjanović Jeromela}

Sažetak: Seme sedam različitih genotipova manje gajene biljne vrste Carthamus tinctorius L. (Asteraceae), dela kolekcije alternativnih uljanih vrsta Instituta za ratarstvo i povrtarstvo (Novi Sad, Srbija), je analizirano na sadržaj proteina, ulja, masnih kiselina, tokoferola i ukupnih fenola, kako bi se ispitala njihova raznovrsnost i potencijal upotrebe ove vrste kao alternativnog izvora ovih, značajnih jedinjenja. Sadržaj proteina (određen metodom po Kjeldahl-u) u semenu šafranike bio je od 11.5 do $16.0 \%$, dok je ukupan sadržaj ulja (određen metodom po Soxhlet-u), u proseku bio od 16.8 do $24.5 \%$ suve materije. Dominantne nezasićene masne kiseline u semenu šafranike bile su oleinska i linolna kiselina, koje predstavljaju približno 90\% ukupnog sadržaja masnih kiselina (određen gasnohromatografski). Najzastupljenija masna kiselina u svim genotipovima je linolna kiselina (61.2-80.2\% ulja), dok je oleinska kiselina bila u negativnoj korelaciji sa sadržajem linoleinske kiseline i bila je u rasponu od 9.6 do $29.5 \%$ ulja. Količina zasićenih masnih kiselina kretala se u rasponu od 5.5 do $6.05 \%$ za palmitinsku i od 2.1 do $3.5 \%$ za stearinsku kiselinu. Seme šafranike je značajni izvor $\alpha$-tokoferola (određen metodom tečne hromatografije visokih performansi sa fluorescencentnim detektorom) i njegova količina se kretala od 358.8 do $461.8 \mathrm{mg} / 1$ ulja. Sadržaj ukupnih polifenola varirao je između 4 i 6 mg ekvivalenata galne kiseline/g suve materije. Analiza datih genotipova semena šafranike ukazuje na značaj ove alternativne uljarice kao dobrog izvora važnih hranljivih sastojaka i bioaktivnih jedinjenja.

Ključne reči: alternativne uljane kulture, Carthamus tinctorius L., masne kiseline, nutritivni kvalitet, proteini, šafranika, tokoferoli, ukupni fenoli, ulja, $\alpha$-tokoferol

This article is distributed under the terms of the Creative Commons Attribution 4.0 International License (http://creativecommons.org/licenses/by/4.0), which permits unrestricted use, distribution and reproduction in any medium, provided you give appropriate credit to the original author(s) and the source, provide a link to the Creative Commons license, and indicate if changes were made. 